\title{
Nursing Students' Competencies in Evidence Based Practice
}

\author{
Chrisnawati", Imelda Ingir Ladjar, Dwi Martha Agustina and Sabarina Oktarina \\ School of Health and Sciences, Suaka Insan Banjarmasin \\ Jalan Haji Zafry Zam - Zam No. 8 Banjarmasin South Borneo, Indonesia 70119 \\ *Corresponding author: yudhachris16@gmail.com
}

\begin{abstract}
Background: The world of nursing is growing and nurses are requiring being proficiencies and establishing their professional responsibility in health care services, especially in giving their best intervention for the wellness of their patients. Therefore, the nursing students are requiring earlier becoming competence in application of Evidence based practice learning during the education period. Objectives: This study aims to determine the competencies in term of knowledge, attitudes and skills in Evidence based practice among nursing students in STIKES Suaka Insan Banjarmasin. Methods: This study administered quantitative and qualitative research design by using 3 variables; knowledge, skill, and attitude. Results: The competencies in Evidence based practice among nursing students in STIKES Suaka Insan Banjarmasin are mostly in moderate high category about 35 respondents (66,03\%), mean score 83 and SD 8,80 with the following: Knowledge of EBP among nursing students are in the most high score is in category of moderate high about 44 respondents (83,01\%), mean score 21,54 and SD 2,15; Skill of EBP the most higher score is in category of moderate high about 41 respondents (77,35\%), mean score 20,22 and SD 3,46; and Attitude toward EBP the most higher score is in high category about 27 respondents (50,94\%), mean score 4,22 and SD 4,83. Conclusion: The competencies in Evidence based practice among nursing students in STIKES Suaka Insan Banjarmasin with highest component is the attitude, follow with knowledge and the lowest component is skill of EBP. Therefore, a lot of program requiring need to developing and establishing nursing student capability in EBP during their education time.
\end{abstract}

Keywords: Evidence Based Practice, Nursing Student, Competence

\section{INTRODUCTION}

The journey to become a professional nurse is started with nursing education as a basic foundation. In Indonesia, nursing education is considered as a higher education and integrated in the national higher education system to meet the demands of the society. The nurse graduates should be able to achieve the unit of competences as learning outcomes to become a professional nurse and be capable in cognitive, psychomotor, and attitude aspect. The nurse graduates are expected to conduct the research independently and apply some findings regarding the development of science and technology in order to improve the quality of nursing care and its process (Simamora, 2009). Evidence Based Practice (EBP) is declared as a crucial standard in providing the best and effective approach for nursing practice (Ashktorab et al, 2015; Cruz et al, 2016). The context of Evidence Based Practice (EBP) is not only focused on nursing practice but its concept has to be integrated in the curriculum of nursing education and shared in the whole wide world (Yildiz \& Gungormus, 2016). Evidence-Based Practice in the nursing curriculum has spread around the world aiming to familiarize students with research that will have a positive effect on students' critical thinking on evidence-based practice. Evidence-based Practice is needed to understand, recognize, and apply 
evidence-based practice policies and have a critical attitude towards nursing practice and to evidence from studies in order to best practice.

It is considered as a new competence and important subject to be mastered by nursing students. In 2011, The American Association of Colleges of Nursing (AACN) and The Institute of Medicine (IOM) emphasized that EBP is not only an essential competency of nursing graduates, but it has to be practiced during the nursing education. By exposing the nursing students with the concept of EBP will directly open their mind and increase their knowledge and positive attitude regarding EBP. Hence, it is important to insert the EBP in nursing education (Smith, 2015).

Evidence-based practice is one of the courses in nursing collage of STIKES Suaka Insan were 4 years applied as a program for BSN students, which aimed for developing and established critical thinking skills, clinical decision making, application of informatics in nursing and preparing for globalization.. Then, through this program evaluation to measure the ability of students about evidence based practice to be prepared for the advanced program.

\section{METHOD}

This study administered quantitative and qualitative research design by using 3 variables; knowledge, skill, and attitude. The descriptive quantitative study utilized the survey questionnaire distributed to 53 nursing students. The survey questionnaire was consisted the statements about Evidence Based Practice Evaluation Competence Questionnaire (EBP-COQ) (Ruzafa-Martine, 2013). It has undergone the validity and reliability test with the value of chronbach Alpha 0.892 in 23 items. The result of the study in terms of the competencies were stated; 85-115 indicated as good, 54-84 indicated as enough, 23-53 less. Knowledge 24-30 indicated as good, 15-23 indicated as enough, 6-14 indicated as less, skill indicated as 24-30 good, 15-23 indicated as enough, 6-14 was less, and the attitude was 41-55 good, 26-40 was enough and 11-25 was less. This study also administered frequency distribution, mean, and standard deviation to analyze the descriptive data. In order to gather the qualitative data, the researchers were conducting the Focus Group Discussion among 7 respondents within 53 nursing students.

\section{RESULTS AND DISCUSSION}

Table 1 Nursing Student Competencies in Evidence based practice

\begin{tabular}{cccc}
\hline No & Categories & F & $\%$ \\
\hline 1 & High & 18 & 33,96 \\
2 & Average & 35 & 66,03 \\
3 & Below & 0 & 0 \\
\hline Total & 53 & 100 \\
\hline & Mean Score & 83 & Fair \\
\hline
\end{tabular}

Table 1 showed that majority the nursing students were having sufficient competency towards evidence based practice. The mean value of each respondent was 83 from the range of value 23 to 115 . It emphasized the competency that the nursing students have. Standard deviation was used to determine the diversity or variation of the students' competency which showed 8.80 as the value. It described that the competency in Evidence Based Practice subject among the students was not different or moderate.

Table 2 Nursing Student Competencies in Evidence based practice in term of level of Knowledge 


\begin{tabular}{cccc}
\hline No & Categories & F & $\%$ \\
\hline 1 & High & 9 & 16,98 \\
2 & Moderate & 44 & 83,01 \\
3 & Below & 0 & 0 \\
\hline & Total & 53 & 100 \\
\hline & Mean Score & 21,54 & Fair \\
\hline & Standard Deviation & 2,15 &
\end{tabular}

Table 2 shows that most of the knowledge of nursing students in Evidence Based Practice learning in the category is sufficient. The mean value of the total score of each respondent is 21.54 from the range of values 6 to 30 which means that the average knowledge of nursing students in the Evidence Based Practice study is categorized as sufficient. With a standard deviation value of 2.15 which means that knowledge in Evidence Based Practice learning between one student and another student in the sample has a moderate diversity or not much different.

Table 3 Nursing Student Competencies in Evidence based practice in term of level of Skill

\begin{tabular}{cccc}
\hline No & Categories & F & $\%$ \\
\hline 1 & High & 10 & 18,86 \\
2 & Moderate & 41 & 77,35 \\
3 & Below & 2 & 3,77 \\
\hline & Total & 53 & 100 \\
\hline & Mean Score & 20,22 & Fair
\end{tabular}

Table 3 showed that most of the nursing students' skills in Evidence Based Practice learning in the category are sufficient. The mean value of the total score of each respondent is 20.22 from the range of values 6 to 30 which means that the average of nursing students' skills in the Evidence Based Practice study is categorized as sufficient. With a standard deviation value of 3.46 which means that the skills in Evidence Based Practice learning between one student and another student in the sample has a moderate diversity or not much different.

Table 4 Nursing Student Competencies in Evidence based practice in term of level of Attitude

\begin{tabular}{cccc}
\hline No & Categories & F & $\%$ \\
\hline 1 & High & 26 & 49,05 \\
2 & Moderate & 27 & 50,94 \\
3 & Below & 0 & 0 \\
\hline & Total & 53 & 100 \\
\hline & Mean Score & 41,22 & Good \\
\hline
\end{tabular}

Table 4 indicate that the attitude of nursing students in the Evidence Based Practice learning is mostly in the sufficient category. However, the results of the study also show that there is a small percentage difference between nursing students who are sufficient with nursing students who are good towards Evidence Based Practice which is about $1.89 \%$. Therefore, the average value of the mean score of the total score of each respondent is 41.22 from the range of values 11 to 55 which means that the average attitude of nursing students to Evidence Based Practice fall into either category. With a standard deviation value of 4.83 which means the attitude toward Evidence Based Practice between one student and another student in the sample has moderate or not different diversity. 


\section{Qualitative Results}

From qualitative research conducted by Focus Group Discussion (FGD) method which try to find answer from nonconformity obtained from result of quantitative research, that is why nursing student have better attitude than knowledge and skill in learning Evidence Based Practice got result that respondents liked the learning of Evidence Based Practice because after following the learning for one semester, the respondents felt that Evidence Based Practice is very important in the world of nursing that helps students and nurses in developing competence to improve the quality of nursing. Nevertheless, there is still an attitude of poor responders regarding the real application of Evidence Based Practice in practice areas that occur because the students have never practiced this directly on the patient's management, so the students are not accustomed and do not feel the benefits directly.

The respondents felt that they had not fully understood the lesson, so they still lacked the knowledge and skills in Evidence Based Practice. In terms of knowledge, respondents find it difficult to understand journals used for using English, lack of student motivation for selfstudy, and lack of understanding of the design and level of evidence. In skills, students feel that they are not maximized in critical appraisal in scientific articles that occur because they do not understand foreign languages, too much information in scientific articles to read, and difficulty in finding points for critical appraisal.

\section{CONCLUSION}

Competence of ninth graders of VIII class VIII in Evidence Based Practice at STIKES Suaka Insan Banjarmasin in 2017 is in enough category with the highest component is attitude, then knowledge, and the lowest is skill. Which happens because students feel that Evidence Based Practice is a very important thing in the world of nursing. However, the students do not yet have a strong desire to practice Evidence Based Practice in practice, where the attitude occurs because the students have never practiced directly in patient management during or after the Evidence Based Practice study. While the knowledge and skills that have not been maximized in Evidence Based Practice learning occur because of lack of foreign language mastery and understanding of statistics and research methodology.

\section{ACKNOWLEDGEMENT}

The authors would like to express the gratitude for our beloved nursing student for their participation during the collecting data for our research and also to institution STIKES Suaka Insan for all supports.

\section{REFERENCES}

Ashktorab, T., Pashaeypoor, S., Rassouli, M., et al. (2015). Nursing Students Competencies in Evidence-Based Practice and its Related Factors. Nurs Midwifery Stud: 1-5.

Cruz, J. P., Colet, P. C., Alquwez, N., et al. (2016). Evidence-Based Practice Beliefs and Implementation among the Nursing Bridge Program Students of a Saudi University. Internasional Journal of Health Sciences: Qassium University. Vol. 10. No. 3: 1-10.

Ellis, J. R., Hartley, C. L. (2012). Nursing in Today's World: Trends, Issues, and Management $10^{\text {th }}$ edition. China: Wolters Kluwer.

Finotto, S., Carpanoni, M., Turroni, E. C., et al. (2013). Teaching Evidence-Based Practice: Developing A Curriculum Model to Foster Evidence-Based Practice in Undergraduate Student Nurses. Nurse Education in Practice 13: 459-465. 
Grove, S. K., Gray, J. R., dan Burns, N. (2015). Understanding Nursing Research Building an Evidence-based Practice $6^{\text {th }}$ Edition. China: Elsevier.

Hung, H. Y., Huang, Y. F., Tsai, J. J., et al. (2015). Current State of Evidence Based Practice Education for Undegraduate Students in Taiwan: A Questionnaire Study. Nurse Education Today: 1-26.

Jalali-Nia, S. F., Salsali, M., Dehghan-Nayeri, N., et al. (2011). Effect of Evidence-Based Education on Iranian Nursing Students' Knowledge and Attitude. Nursing \& Health Sciences 13: 221-227.

Janke, R., Pesut, B., Erbacker, L. (2011). Promoting Information Literacy Through Collaborative Service Learning in an Undergraduate Research Course. Nurse Education Today 32: 920-923.

McEwen, M dan Wills, E. M. (2014). Theoretical Basis for Nursing Fourth Edition. China: Wolters Kluwer.

Melnyk, B. M dan Fineout-Overholt, E. (2015). Evidence-Based Practice in Nursing and Healthcare A Guide to Best Practice Third Edition. China: Wolters Kluwer.

Moch, S. D., Cronje, R. J., Branson, J. (2010). Part 1. Undegraduate Nursing Evidence-Based Practice Education: Envisioning The Role of Students. Journal of Professional Nursing vol. 26. No. 1:5-13.

Ruzafa-Martinez, M., Lopez-Iborra, L., Barranco, D, A., et al. (2015). Effectiveness of an Evidence-based Practice (EBP) Course on the EBP Competence of Undegraduate Nursing Students: A Quasy-experimental Study. Nurse Education Today: 1-6.

Simamora, R. H. (2009). Buku Ajar Pendidikan dalam Keperawatan. Jakarta: EGC.

Smith, M. J., Fitzpatrick, et al. (2015). Encyclopedia of Nursing Education. Springer Publishing Company.

Weston, M. J. (2010). Strategies for Enhancing Autonomy and Control Over Nursing Practice. The Online Journal of Issues in Nursing (OJIN).

Yildiz, E \& Gungormus, Z. (2016). The Validity and Reability Study of The Turkish Version of the Evidence Based Practice Evalution Competence Questionnaire. Nurse Education Today 45: 1-5.

Zhang, Q., Zeng, T., Chen, Y., et al. (2012). Assisting Undergraduate Nursing Students to Learn Evidence-Based Practice Through Self-Directed Learning and Workshop Strategies During Clinical Practicum. Nurse Education Today 32: 570-575. 